\title{
Decision Support System for Determining Exemplary Students Using SAW Method
}

\author{
Henny Destiana ${ }^{1)}$, Adjat Sudradjat ${ }^{2)^{*}}$, Aprilah Amira Sefenizka ${ }^{3)}$ \\ ${ }^{12)}$ Universitas Bina Sarana Informatika, Indonesia ${ }^{3)}$ STMIK Nusa Mandiri, Indonesia \\ ${ }^{1)}$ henny.hnd@bsi.ac.id, ${ }^{2)}$ adjat.ajt@ bsi.ac.id, ${ }^{3)}$ aprilaha2704@ nusamandiri.ac.id
}

Submitted : Sep 18, 2020| Accepted : Oct 10, 2020 | Published : Oct 10, 2020

\begin{abstract}
In order to motivate students to continue to excel, MTs Al Falah undertakes activities to develop students' potential through determining exemplary students. However, the decision to determine exemplary students is not based on academic and non-academic abilities, but on the subjectivity of the principal and teachers. So that many complain about the decision of the selection of exemplary students who are not well targeted or deserve to be exemplary students. There is no information system that supports the determination of exemplary students on MTs $\mathrm{Al} \mathrm{Falah,} \mathrm{It} \mathrm{is} \mathrm{less} \mathrm{precise} \mathrm{in} \mathrm{determining} \mathrm{the} \mathrm{exemplary} \mathrm{students} \mathrm{on} \mathrm{MTs} \mathrm{Al} \mathrm{Falah,}$ decision support systems in Determination of the Exemplary Students using the Simple Additive Weighting (SAW) method is based on 5 criteria, namely the value of knowledge, the value of skills, class rank, extracurricular activity, extracurricular values. The results obtained will be in the form of exemplary student rankings. The Simple Additive Weight method can help the school especially in determining a number of issues regarding education, one of which is to determine exemplary students. Because this method is a weighted method of rating the performance of each alternative.
\end{abstract}

Keywords: MTs Al Falah; Determining Exemplary Students; Simple Additive Weighting (SAW) Method

\section{INTRODUCTION}

The educational strategies taken so far are general in nature, and provide standard treatment to all students, so that they do not pay attention to differences between students in values, interests, and talents. With this strategy excellence will appear randomly and depend on student motivation. Therefore, it is necessary to develop student assessment efforts selectively with the advantages possessed by each student so that their potential can be converted into exemplary students.

In order to motivate students to continue to excel, MTs Al Falah carries out activities to develop student potential through exemplary student programs. However, the decision making to determine exemplary students is not based on academic and non-academic abilities, but on the basis of the subjectivity of the principal and teachers. So that many have filed complaints about the decision to elect students who are not worthy and not on target.

According to (Hidayat, 2017) "defines a decision support system as a computer-based system consisting of three interacting components, namely language systems, knowledge systems and problem processing systems"

The use of the Decision Support System is expected to eliminate this injustice, selecting exemplary students according to the criteria. The model used in this system is Simple Additive Weighting (SAW). The decision support system in Determining Model Students uses the Simple Additive Weighting (SAW) method based on 5 criteria, namely knowledge values, skill scores, class rankings, extracurricular activeness, extracurricular values.

According to (Liesdiana \& Mauliana, 2017) states that the basic concept of Simple Additive Weighting (SAW) is to find the weighted sum of the performance ratings for each alternative on all attributes. The Simple Additive Weighting (SAW) method requires a process of normalizing the decision matrix (X) to a scale that can be compared with all available alternative ratings.

The research has succeeded in finding a new, more effective way to determine exemplary students at MTs Al Falah with clear criteria and more objective results, using the Simple Additive Weighting method. The school will be firm and confident in the decisions it makes.

\section{LITERATURE REVIEW}

According to (Sari, 2017) Simple Additive Weighting is a method used to find optimal alternatives from a number of alternatives with certain criteria. The essence of Simple Additive Weighting is to determine the weight

\footnotetext{
* Corresponding Author
} 
value for each attribute, then proceed with a ranking process that will select the alternatives that have been given. Basically, there are 3 approaches to finding the value of the attribute weight, namely the subjective approach, the objective approach, and the integration approach between subjective and objective. Each approach has advantages and disadvantages. In a subjective approach, the weight value is determined based on the subjectivity of the decision makers. So that several factors in the alternative ranking process can be determined freely. Whereas in the objective approach, the weight value is calculated mathematically so that it ignores the subjectivity of the decision maker.

The Settlement steps in using Simple Additive Weighting as follows:

1. Determine alternatives (candidates).

2. Determine the criteria that will be used as a reference in making decisions.

3. Provide a rating of the suitability of each alternative on each criterion.

4. Determine the weight of preference or level of importance for each criterion.

5. Creating a rating table of the suitability of each alternative on each criterion.

6. Create a decision matrix $X$ formed from the suitability rating table of each alternative on each criterion. The $X$ value of each alternative on each predetermined criterion.

7. Normalize the decision matrix $\mathrm{X}$ by calculating the normalized performance rating value of the alternative Ai on the $\mathrm{Cj}$ criterion. By grouping, whether $\mathrm{j}$ is a benefit criterion or a cost criterion, the meaning is:

8. The results of the normalized performance rating (rij) form a normalized matrix.

9. The final result of preference value is obtained from the sum for each of the row elements normalized matrix $(\mathrm{R})$ with the preference weight $(\mathrm{W})$ corresponding to the matrix column element $(\mathrm{W})$. The result of a larger $\mathrm{Vi}$ value indicates that the alternative $\mathrm{A} i$ is the best alternative.

10. Determine the indication value.

11. Ranking is done by multiplying the Simple Additive Weighting value with the indicated value and the final result of the value will be ranked according to the order of results having the highest to the smallest values.

The formula for carrying out the normalization is as following :

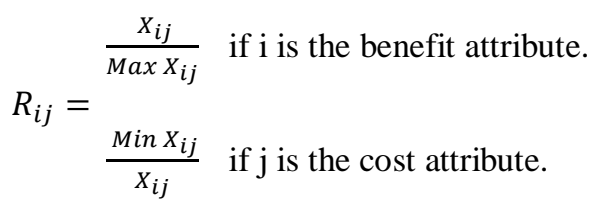

Information :

$\mathrm{R}_{\mathrm{ij}} \quad=$ Normalized performance rating

$\operatorname{Max} X_{i j}=$ The maximum value of each line and column

Min $X_{i j}=$ Minimum value of each line and column

$\mathrm{X}_{\mathrm{ij}} \quad=$ Rows and columns of matrix

Benefit = If the greatest value is the best

Cost $=$ If the smallest value is best

Information:

$$
V_{i}=\sum_{j=1}^{n} W_{j} R_{i j}
$$

$\mathrm{V}_{\mathrm{i}}=\quad$ Final value of alternatives

$\mathrm{W}_{\mathrm{j}}=\quad$ Weight has been determined

$\mathrm{R}_{\mathrm{ij}}=\quad$ Normalized matrix, a larger $\mathrm{Vi}$ value indicates that the alternative Ai is preferred

\section{METHOD}

The research attempted to collect accurate data and information that could support the research process and results in the research. The research attempted to collect accurate data and produce objective information, so that it can be used by the school as a valid reference source in supporting decision making regarding exemplary students at MTs Al Falah.

\section{Data Collection Techniques}

1. Observation

The author made observations in MTs Al Falah to determine the exemplary student. And the authors also get the data needed in writing this research such as knowledge value, skill scores, class rankings, extracurricular activeness, extracurricular values.

2. Interview

In the research, in order to obtain accurate information, the authors conducted interviews with the principal in determining the exemplary student. 
3. Literature study

In data collection techniques with this literature study, the author collects data sources from several books that the author gets.

\section{Data Based on Sources}

Based on the source, the data collection of this research is as follows:

1. By making direct observations, interviews to obtain primary data.

2. Secondary data comes from collecting and identifying and managing written data in the form of books and journals related to research.

\section{Population and Research Sample}

In this study, researchers conducted observations and direct interviews with the principal of MTs Al Falah Bekasi. The population will be taken from students who meet the criteria in determining exemplary students. 10 samples along with their values are described below.

Table 1.

Research Sample

\begin{tabular}{clccccc}
\hline \hline No. & Name & C1 & C2 & C3 & C4 & C5 \\
\hline 1 & Fauzan Putra Safriza Lanoni & 1304 & 1330 & 1 & 12 & A \\
2 & Afifah Angelia Azhariyanti & 1363 & 1359 & 2 & 10 & B \\
3 & Fairus Diantha Pradakyla & 1330 & 1336 & 3 & 11 & A \\
4 & Farah Zakia Badriati & 1303 & 1332 & 5 & 11 & B \\
5 & Heni Komala Dewi & 1275 & 1320 & 10 & 11 & A \\
6 & Kresna Suherman Sakha Wahida & 1256 & 1312 & 15 & 10 & A \\
7 & Naomi Natasha Joshe Putri & 1274 & 1311 & 11 & 10 & A \\
8 & Revia Allifa & 1271 & 1334 & 8 & 11 & B \\
9 & Rohmani Fi Amanilah & 1366 & 1360 & 1 & 8 & B \\
10 & Sahla Sania Azzahwa & 1310 & 1329 & 4 & 8 & B
\end{tabular}

Source : (Research Result, 2020)

\section{RESULT}

Based on the general research carried out in the process of determining exemplary students, in this study each student will be assessed based on the criteria and alternatives that will be tested using the Simple Additive Weighting method, as follows

\section{Criteria}

In determining exemplary students at MTs Al Falah Bekasi, several criteria have been applied.

Table 2.

Criteria Conditions

\begin{tabular}{cc}
\hline Code & Criteria \\
\hline C1 & Value of Knowledge \\
C2 & Skill Value \\
C3 & Class Rating \\
C4 & Extracurricular Activities \\
C5 & Extracurricular Value \\
\hline Source : (Research Result, 2020)
\end{tabular}

\section{Determine the weight of each criterion}

The weights of each criterion are differentiated for a more structured assessment. This weight is obtained directly from the results of an interview with the Principal of MTs Al Falah Bekasi.

Table 3

Weight Determination

\begin{tabular}{ccc}
\hline Code & Range \% & Weight $(\mathbf{W})$ \\
\hline C 1 & $25 \%$ & 0.25
\end{tabular}




\begin{tabular}{ccc} 
C2 & $30 \%$ & 0.3 \\
C3 & $10 \%$ & 0.1 \\
C4 & $20 \%$ & 0.2 \\
C5 & $15 \%$ & 0.15 \\
\hline Source : (Research Result, 2020)
\end{tabular}

Source : (Research Result, 2020)

\section{Criteria Rating Scale}

The rating scale follows the rating scale used in determining exemplary students at MTs Al Falah Bekasi.

Table 4

Knowledge Value Rating Scale

\begin{tabular}{ccc}
\hline Range & Description & Value \\
\hline $1150-1199$ & Very Low (SR) & 1 \\
$1200-1249$ & Low (R) & 2 \\
$1250-1299$ & Enough (C) & 3 \\
$1300-1349$ & High (T) & 4 \\
$1350-1399$ & Very High (ST) & 5 \\
\hline
\end{tabular}

Source : (Research Result, 2020)

Table 5

Skill Rating Scale

\begin{tabular}{ccc}
\hline \hline Range & Description & Value \\
\hline $1150-1199$ & Very Low (SR) & 1 \\
$1200-1249$ & Low (R) & 2 \\
$1250-1299$ & Enough (C) & 3 \\
$1300-1349$ & High (T) & 4 \\
$1350-1399$ & Very High (ST) & 5 \\
\hline
\end{tabular}

Source : (Research Result, 2020)

Table 6

Class Rating Scale

\begin{tabular}{ccc}
\hline Range & Description & Value \\
\hline $23-28$ & Very Low (SR) & 1 \\
$18-22$ & Low (R) & 2 \\
$13-17$ & Enough (C) & 3 \\
$8-12$ & High (T) & 4 \\
$1-7$ & Very High (ST) & 5 \\
\hline
\end{tabular}

Source : (Research Result, 2020)

Table 7

Extracurricular Activity Rating Scale

\begin{tabular}{ccc}
\hline \hline Range & Description & Value \\
\hline 0 & Very Low (SR) & 1 \\
$3-1$ & Low (R) & 2 \\
$6-4$ & Enough (C) & 3 \\
$9-7$ & High (T) & 4 \\
$12-10$ & Very High (ST) & 5 \\
\hline
\end{tabular}

Source : (Research Result, 2020)

Table 8

Extracurricular Value Rating Scale

\begin{tabular}{ccc}
\hline \hline Range & Description & Value \\
\hline E & Very Low (SR) & 1 \\
D & Low (R) & 2 \\
C & Enough (C) & 3 \\
B & High (T) & 4 \\
A & Very High (ST) & 5 \\
\hline
\end{tabular}

Source : (Research Result, 2020) 


\section{Determine the Rating Value}

Determine the suitability rating of each alternative on each of the criteria specified above as follows:

Table 9.

Rating Value

\begin{tabular}{clccccc}
\hline \hline No. & Name & C1 & C2 & C3 & C4 & C5 \\
\hline 1 & Fauzan Putra Safriza Lanoni & 4 & 4 & 5 & 5 & 5 \\
2 & Afifah Angelia Azhariyanti & 5 & 5 & 5 & 5 & 4 \\
3 & Fairus Diantha Pradakyla & 4 & 4 & 5 & 5 & 5 \\
4 & Farah Zakia Badriati & 4 & 4 & 5 & 5 & 4 \\
5 & Heni Komala Dewi & 3 & 4 & 5 & 5 & 5 \\
6 & Kresna Suherman Sakha Wahida & 3 & 4 & 3 & 5 & 5 \\
7 & Naomi Natasha Joshe Putri & 3 & 4 & 4 & 5 & 5 \\
8 & Revia Allifa & 3 & 4 & 4 & 5 & 4 \\
9 & Rohmani Fi Amanilah & 5 & 5 & 5 & 4 & 4 \\
10 & Sahla Sania Azzahwa & 4 & 4 & 5 & 4 & 4
\end{tabular}

Source : (Research Result, 2020)

\section{Determine the Matrix}

After the alternative rating value for each criterion is determined, then a decision matrix $(\mathrm{X})$ is formed which is formed from the suitability rating table of each alternative on each criterion.

$\left|\begin{array}{lllll}4 & 4 & 5 & 5 & 5 \\ 5 & 5 & 5 & 5 & 4 \\ 4 & 4 & 5 & 5 & 5 \\ 4 & 4 & 5 & 5 & 4 \\ 3 & 4 & 5 & 5 & 5 \\ 3 & 4 & 3 & 5 & 5 \\ 3 & 4 & 4 & 5 & 5 \\ 3 & 4 & 4 & 5 & 4 \\ 5 & 5 & 5 & 4 & 4 \\ 4 & 4 & 5 & 4 & 4\end{array}\right|$

\section{Normalized Matrix}

The results of the normalized matrix (Rij) form a normalized matrix (R).
Information :
Rij $\quad=$ Normalized performance rating
Max Xij $=$ The maximum value of each line and column
Xij $\quad=$ Rows and columns of matrix
Benefit $\quad=$ If the greatest value is the best

$\begin{array}{|ccccc|}0.8 & 0.8 & 1 & 1 & 1 \\ 1 & 1 & 1 & 1 & 0.8 \\ 0.8 & 0.8 & 1 & 1 & 1 \\ 0.8 & 0.8 & 1 & 1 & 0.8 \\ 0.6 & 0.8 & 1 & 1 & 1 \\ 0.6 & 0.8 & 0.6 & 1 & 1 \\ 0.6 & 0.8 & 0.8 & 1 & 1 \\ 0.6 & 0.8 & 0.8 & 1 & 0.8 \\ 1 & 1 & 1 & 0.8 & 0.8 \\ 0.8 & 0.8 & 1 & 0.8 & 0.8\end{array}$




\section{Value Preference}

The final step is the search process for the ranking of preference values or the best value by entering each criterion and weight value used in this ranking, namely $\mathrm{W}=(0.25,0.3,0.1,0.2,0.15)$.

$$
V_{i}=\sum_{j=0}^{n} W_{j} R_{i j}
$$

A larger $\mathrm{Vi}$ value indicates that alternative $\mathrm{Ai}$ is preferred.

Information :

$\mathrm{V}_{\mathrm{i}} \quad=$ ranking for each alternative

$\mathrm{W}_{\mathrm{j}} \quad=$ weight value of each performance

$\mathrm{R}_{\mathrm{ij}} \quad=$ normalized performance weight value

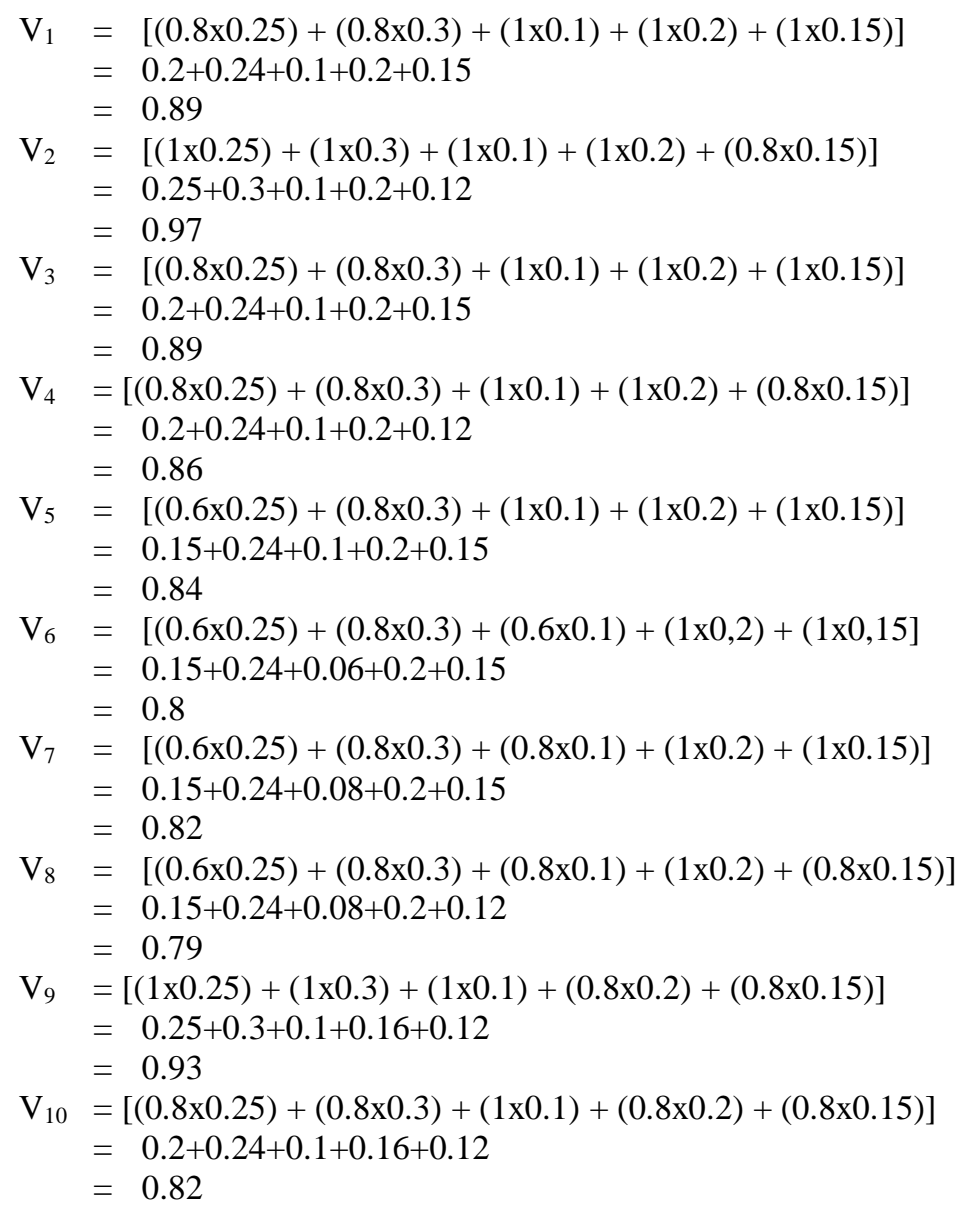

\section{Ranking Results}

The results of ranking the preference values of each alternative with the $V_{i}$ value are as follows:

Table 10

Ranking Results

\begin{tabular}{clcc}
\hline \hline No. & Name & Code & Value \\
\hline 1 & Afifah Angelia Azhariyanti & A2 & 0.97 \\
2 & Rohmani Fi Amanilah & A9 & 0.93 \\
3 & Fauzan Putra Safriza Lanoni & A1 & 0.89 \\
4 & Fairus Diantha Pradakyla & A3 & 0.89 \\
5 & Farah Zakia Badriati & A4 & 0.86 \\
6 & Heni Komala Dewi & A5 & 0.84 \\
7 & Naomi Natasha Joshe Putri & A7 & 0.82 \\
8 & Sahla Sania Azzahwa & A10 & 0.82 \\
9 & Kresna Suherman Sakha Wahida & A6 & 0.8 \\
10 & Revia Allifa & A8 & 0.79 \\
\hline Source $:$ (Research Result, 2020) & &
\end{tabular}


From the calculation above, it can be determined that students who have the right to become exemplary students where only students who have a value of $>0.80$ are included in the category of model students. The greatest value on $V_{2}$ is the best alternative $A_{2}$ (student 2) with a final result of 0.97 , but in this case the best alternative is some students who get sufficient weighted scores on each criterion.

\section{DISCUSSION}

From the results of the research conducted by the author, it can be suggested some suggestions for further research as follows:

1. From a managerial perspective, this research can be applied in other schools. In order to be able to help the school to solve things in decision making. Research can also be carried out and developed with other research methods, such as simple additive weighting.

2. Research can be further developed with different criteria according to the criteria and weight determined from the place where the research was conducted.

3. Hopefully what has been produced in this study can be useful and can help the MTS AL FALAH Bekasi school in making decisions to determine model students. This research is still far from perfect, therefore constructive input, suggestions, and criticism are needed to improve this research for the better.

\section{CONCLUSION}

The results of the discussion of the research that has been done prove that the decision support system using the Simple Additive Weighting method is able to determine exemplary students at MTs Al Falah effectively and objectively. Based on the criteria for knowledge scores, skill scores, class rankings, extracurricular activeness, and extracurricular scores, those who are selected as exemplary students are those who have grades above 0.80. From the calculated sample, the student who got the highest score in the five categories with a percentage value of 0.97 was Afifah Angelia Azhariyanti. The Simple Additive Weighting (SAW) method helps the leaders of MTs Al Falah to use a systematic procedure in determining model students with fast, accurate and objective results in the form of decision support recommendations. Further research is expected so that systematic procedures can be developed again in the form of web-based or mobile application programs. All calculations in the Simple Additive Weighting (SAW) method on the input values for each criterion can be processed automatically by the application, so that the leaders of MTs Al Falah can get the result information in numbers and graphs even faster. The application of a web-based or mobile application program also makes it easier for MTs Al Falah leaders to access this information online.

\section{REFERENCES}

Badrul, M., Rusdiansyah, R., \& Budihartanti, C. (2019). Application of Simple Additive Weighting Method for Determination of Toddler Nutrition Status. SinkrOn, 4(1), 19. https://doi.org/10.33395/sinkron.v4i1.10145

Hidayat, R. (2017). Sistem Pendukung Keputusan Penerima Beasiswa Murid Berprestasi dengan Metode Simple Additive Weighting. SISFOTEK GLOBAL, 7(2), 34-37. https://doi.org/10.30743/infotekjar.v2i1.160

Liesdiana, S. F., \& Mauliana, P. (2017). Sistem Pendukung Keputusan Penentuan Kontrak Kerja Agent Call Center Menggunakan Metode SAW. Jurnal Informatika, 4(1), 76-81. https://ejournal.bsi.ac.id/ejurnal/index.php/widyacipta/article/view/2989/2045

Retnasari, T., Prihatin, T., \& Fikri, M. (2019). A Determination of The Best Employees using Simple Additive Weighting (SAW) Method. SinkrOn, 4(1), 106. https://doi.org/10.33395/sinkron.v4i1.10169

Sari, F. (2017). Metode Dalam Pengambilan Keputusan (Cetakan Pe). Deepublish.

Wati, E. F., Istikharoh, I., \& Tuslaela, T. (2020). Selection of Outstanding Lecturers with Simple Additive Weighting Method. SinkrOn, 4(2), 62. https://doi.org/10.33395/sinkron.v4i2.10513

Darmawan, Aditia, and Esty Purwaningsih. 2019. "Sistem Informasi Pendukung Keputusan Kinerja Karyawan Dengan Metode Simple Additive Weighting Pada PT. Anggada Perkasa Tehnik." Informatics For Educators and Professionals 4(1):23-32.

Fiqih, Muhamad, and Yahdi Kusnadi. 2017. "Sistem Pendukung Keputusan Pemilihan Dosen Berprestasi Dengan Metode Simple Additive Weighting." Information System For Educators And Professionals 2(1):41-50.

Frieyadie. 2017. "Penggunaan Metode Simple Additive Weighting Penentuan Kelayakan Pemberian Beasiswa Untuk Siswa Berprestasi.” Jurnal Ilmu Pengetahuan Dan Teknologi Komputer 3(1):17-22.

Khasanah, Fata Nidaul. 2019. "Metode Simple Additive Weighting Untuk Mendukung Pemilihan Laptop." PIKSEL $\square$ : Penelitian Ilmu Komputer Sistem Embedded and Logic 7(1):91-100.

Khasanah, Fata Nidaul, and Syahbaniar Rofiah. 2019a. "Metode Simple Additive Weighting Dalam Menentukan Rekomendasi Penerima Beasiswa." Bina Insani ICT Journal 6(1):65-74.

Khasanah, Fata Nidaul, and Syahbaniar Rofiah. 2019b. "Sistem Seleksi Penerimaan Beasiswa Menggunakan Metode Pendukung Keputusan Simple Additive Weighting." Pp. 118-25 in Seminar Nasional APTIKOM (SEMNASTIK). Semarang: Universitas Dian Nuswantoro.

Khasanah, Fata Nidaul, and Didik Setiyadi. 2019. "Uji Sensitivitas Metode Simple Additive Weighting Dan Weighted Product Dalam Menentukan Laptop.” Bina Insani ICT Journal 6(2):165-74. 
Murtina, Hidayanti, and Mely Mailasari. 2017. "Pengukuran Tingkat Reliabilitas Metode Simple Additive Weighting Menggunakan Metode Pearson Correlation." Information System for Educators and Professionals 2(1):21-30.

Nofriansyah, Dicky. 2014. Konsep Data Mining Vs Sistem Pendukung Keputusan. Yogyakarta: Deepublish.

Siregar, Bangga Tua, and Herlawati. 2017. "Sistem Informasi Pemilihan Siswa Terbaik SMP Tinta Emas Indonesia." Jurnal Mahasiswa Bina Insani 2(1):37-48.

Yulianti, Erni, Tuti Haryanti, and Laela Kurniawati. 2014. "Sistem Penunjang Keputusan Penerimaan Beasiswa Pegawai Dengan Metode Fuzzy MADM.” Sniptek (ISBN:978-602-72850-5-7):39-46. 